\title{
A review of the New World Atteva Walker moths (Yponomeutidae, Attevinae)
}

\author{
Vitor O. Becker ${ }^{1}$
}

${ }^{1}$ Reserva Serra Bonita, P. O. Box 001, 45880-970 Camacan-BA, Brazil. becker.vitor@gmail.com

\begin{abstract}
A review of the New World Atteva Walker moths (Yponomeutidae, Attevinae). The New World species of Atteva Walker are reviewed and illustrated in colour. One name: A. pustulella (Fabricius), nom. rev. and three species: A. aurea (Fitch), sp. rev., A. floridana (Neumoegen), sp. rev. and A. gemmata (Grote), sp. rev. are reinstated; five names are synonymised under A. aurea: Poeciloptera compta Clemens, syn. n., A. edithella Busck, syn. n., A. exquisita Busck, syn. n., A. ergatica Walsingham, syn. n. and A. microsticta Walsingham, syn. n.; four new species are described: A. rawlinsi sp. n., from the Dominican Republic, A. sidereoides sp. n., from Jamaica, A. entermedia sp. n., from Antigua, and A. zebrina sp. n., from Brazil; lectotypes for A. floridana and A. glaucopidella (Guenée) (=fulviguttata) are also designated.
\end{abstract}

KEYWORDS. Microlepidoptera; New World; nomenclature; taxonomy.

\begin{abstract}
RESUMO. Resenha das mariposas do gênero Atteva Walker do Novo Mundo (Yponomeutidae, Attevinae). As species de Atteva Walker são revistas e ilustradas em cores. Um nome: A. pustulella (Fabricius), nom. rev. e três espécies: A. aurea (Fitch), sp. rev., A. floridana (Neumoegen), sp. rev. and A. gemmata (Grote), sp. rev. são restabelecidos; cinco nomes são considerados sinônimos recentes de A.aurea: Poeciloptera compta Clemens, syn. n., A. edithella Busck, syn. n., A. exquisita Busck, syn. n., A. ergatica Walsingham, syn. n. e A. microsticta Walsingham, syn. n.; quatro espécies novas são descritas: A. rawlinsi sp. n., da República Dominica, A. sidereoides sp. n., da Jamaica, A. entermedia sp. n., de Antigua, e A. zebrina sp. n., do Brazil; são designados lectótipos para A. floridana e A. glaucopidella (Guenée) (=fulviguttata).
\end{abstract}

PALAVRAS-CHAVE. Microlepidoptera; nomenclatura; Novo Mundo; taxonomia.

The pantropical genus Atteva Walker, 1854 comprises over 50 species of mostly brightly-coloured, medium-sized moths (Dugdale et al. 1999: 122) some of which are common. A total of 15 species are present in the New World, including the four new ones described here.

The New World members of the genus have never been reviewed and most of them never illustrated. The few which were are in scattered and mostly old literature not easily available. An illustrated treatment is presented here to allow identification of the species occurring in the New World.

Nearly 3,000 specimens, including type-material, deposited in the National Museum of Natural History in Washington (USNM), the Carnegie Museum in Pittsburgh (CMNH), the Natural History Museum in London (BMNH), and in the author's collection in Camacan, Bahia, Brazil (VOB), were examined. Other type material studied here is deposited in the following institutions: Naturhistorisches Museum in Vienna (NM), the Museum für Naturkunde der Humboldt-Universität in Berlin (MNHU) and the Academy of Natural Sciences in Philadelphia (ANS). More than $90 \%$ of the specimens examined belong to the widespread pustulella-aurea complex. Abbreviations for States of Brazil, México and the United States follow Heppner (1984: xvii-xviii).

The combination of colour pattern with geographical distribution enables easy recognition of the species, whereas characters of the genitalia are very similar throughout the genus so are unreliable for determination. For this reasons illustrations of the latter are omitted.

\section{Atteva Walker}

Atteva Walker, 1854: 526. Type species: Atteva niveigutta Walker, 1854: 526 , by monotypy.

Poeciloptera Clemens, 1861: 546. Type species: Poeciloptera compta Clemens, 1854: 527, by monotypy. A junior homonym of Poeciloptera Loew, 1846 [Diptera]. Synonymized by Berg (1880: 99).

Amblothridia Wallengren, 1861: 385. Type species: Phalaena fabriciella Swederus, 1787: 277, by subsequent designation by Fletcher, 1929: 11. Synonymized by Moore (1867: 669).

Corinea Walker, 1863: 542. Type species: Corinea niviguttella Walker, 1863: 542, by subsequent designation by Fletcher, 1929: 11. Synonymized by Moore (1867: 669).

Oeta Grote, 1865: 231. Type species: Poeciloptera compta Clemens, 1861: 546, by monotypy (of Poeciloptera Clemens), an objective replacement name for Poeciloptera Clemens. Synonymized by Berg (1880: 99).

Carthara Walker, 1866: 1871. Type species: Carthara flavivitta Walker, 1866: 1872, by monotypy. A junior homonym of Carthara Walker, 1865: 914 [Pyralidae]. Synonymized by Walsingham (1914: 327).

Synadia Walker, 1866: 1984. Type species: Carthara flavivitta Walker, 1866: 1871, by monotypy (of Carthara Walker), an objective replacement name for Carthara Walker, 1866. Synonymized by Walsingham (1914: 327).

Scintilla Guenée, 1879: 287. Type species: Tinea pustullella Fabricius, 1787: 241, by monotypy. A junior homonym of Scintilla Deshayes, 1856 [Mollusca]. Synonymized by Berg (1880: 99). 
Syblis Guenée, 1879: 288. Type species: Syblis glaucopidella Guenée, 1879: 289, by monotypy. Synonymized by Berg (1880: 99).

Most of the species belonging to this genus are brightly coloured and easily distinguished by their wing pattern. Their gregarious larvae feed on several plants belonging to the Araliaceae, Fabaceae, Lauraceae and Simaroubaceae (Dugdale et al. 1999: 122), however, in the New World, all known host plant records are members of the two latter families.

The type species, A. niveigutta [=fabriciella Swederus, 1787] is an Indo-Australian species. Therefore, if the New World species prove not to be congeneric with the species of that region, the name Oeta Grote is the oldest, valid and available name to incorporate them.

\section{Atteva pustulella (Fabricius) nom. rev.} (Fig. 1)

Phalaena Tinea punctella Stoll, 1781: 164. Type(s), Surinam [No further data], not examined [lost?]. A junior homonym of Phalaena punctella Linnaeus, 1761.

Tinea pastulella Fabricius, 1787: 241. [A printing error of pustulella,["pustula" = blister] see next]. Objective replacement name for Phalaena Tinea punctella Stoll, 1781.

Tinea pustulella Fabricius, 1794: 292. Correction of T. pastulella Fabricius, 1787.

Lithosia pustulata Fabricius, 1798: 462.

Crameria subtilis Hübner, 1822: 168. Objective replacement name for Phalaena Tinea punctella Stoll, 1781.

This species ranges from Uruguay and Argentina northwards to Costa Rica where it meets aurea. It is also present in the Antilles. There are several specimens from Dominica, Jamaica, Haiti and Martinique in the USNM. This species has the black outlining the markings more developed than other species, the orange areas reduced, with the antemedial and medial orange fasciae each divided into two large blotches.

The larvae have been reared by the author and by D. Janzen (pers. comm.) on the leaves of "azeituno", Simarouba amara (Simaroubaceae) in Costa Rica. The same host is recorded by Sefer (1963: 10-12) [as "marupá", the Amazonian popular name]. Ailanthus altissima is recorded by Berg (1880: 101), Biezanko et al. (1957: 18), Biezanko (1961: 7), Ruffinelli (1967: 22) and Hayward (1969: 72). Laurus nobilis (Lauraceae) is recorded by Biezanko et al. (1957: 18), Biezanko (1961: 7) and by Ruffinelli (1967: 22). Hayward (1969: 72) lists Phoebe porphyria (Lauraceae). Köhler, cited by Hayward (1969: 72) listed Melia azedarach (Meliaceae) as a food plant in Argentina. However, this might be a misidentification as seedlings of this species and those of Ailanthus could be easily confused in the field or either he mixed up the local popular names of the two: "paraíso" and "árbol del cielo", respectively. The same information was repeated by Biezanko et al. (1957: 18), Biezanko (1961: 7), Ruffinelli (1967: 22) and by Hayward (1969: 72), presumably from the same source.

Surprisingly the name punctella, recognized as a junior homonym not long after it's description (Fabricius, 1787: 241; Hübner, 1822: 168) and recognized as such by Walsingham (1914: 330), has been remained in use until now in several major works (Heppner \& Duckworth 1983: 26; Heppner, 1984: 56; Covell 1984: 431; Dugdale et al 1999: 123).

\section{Atteva aurea (Fitch) sp. rev. (Figs. 2-5)}

Deiopeia aurea Fitch, 1856: 486. Type(s), USA: Georgia, Savannah (Dickson) [not traced].

Poeciloptera compta Clemens, 1861: 527. Types(s) [USA]: Texas (Capt. Pope) ["From the Smithsonian Institution"] [not traced]. Syn. rev.

Oeta aurera Stretch, 1873: 240. Misspelling.

Atteva edithella Busck, 1908: 85. Holotype 우, USA: Texas, Maverick Co. (USNM) [examined]. Syn. n.

Atteva exquisita Busck, 1912: 86. Holotype ơ, Mexico: Coa, Mobano, viii (Müller) (USNM) [examined]. Syn. n.

Atteva ergatica Walsingham, 1914: 328. Holotype 오, Belize: Rio Sarstoon (Blancaneaux) (BMNH) [examined]. Syn. n.

Atteva microsticta Walsingham, 1914: 330. Holotype + , Mexico: Pue, Tehuacan, iii.1907 (Müller) (USNM) [examined]. Syn. n.

This species, popularly known as the 'ailanthus webworm moth' in the United States and Canada, is a highly variable species, which explains why it has been described several times. It is very similar to pustulella and for a long time the two have been considered to represent a single species. Their genitalia, included those of all other forms listed above as synonyms, show no difference and no other character, including host-plant and habitat, provides clear evidence to separate the two. The decision to consider the population ranging from Costa Rica south to Uruguay and Argentina as one species - pustulella- and the other, ranging from Northern Costa Rica northwards, along the Gulf of México and Eastern United States, into Canada, including a series of specimens from Jamaica in the USNM, -aurea- as distinct, is based on the results of DNA ("bar-coding"), information provided by D. Janzen (pers. com.). This information was extracted from material belonging to both forms reared by him, side-by-side, on S. amara, in Guanacaste, Costa Rica and from North American specimens. Therefore, distribution is the only safe indication to identify them. Fortunately, the populations of both forms found together in northern Costa Rica, are distinct, making it possible to segregate both, based on the phenotypes. As illustrated in Holland (1903: pl. 48, fig. 36), and Covell (1984: pl. 61, fig. 13), its forewings bear the orange more extended and the marks more reduced than in pustulella. The form microsticta (Fig. 2), described from Puebla, México represented by a long series collected by the author in Zapotitlán, a semidesert area, also in Puebla State, is more similar to pustulella, with yellow areas divided into multiple dots, as indicated by its name. It is synonymized because specimens with a pattern between this and typical aurea (Fig. 3) can be found among material collected in other parts of México. Form exquisita (Fig. 4), described from the semi arid region of northern México, ranges northwest into Southern California and south into Baja California (Powell et al. 1973). This is a paler form, with the blotches on antemedial and medial areas divided vertically into two single areas, however the pattern is also variable as shown by the illustrations given by the above-mentioned 
authors who studied its biology in detail. In the USNM there is a long series from the Big Bend National Park and three specimens from Galeana, Nuevo León, Mexico which include this form, as well as specimens looking like typical aurea. A. edithella (Fig. 5) is no more than another form, similar to exquisita, but paler, with the markings on fore wings even more reduced, as shown in Fig. 9 in the above work.

The presence of aurea in the eastern United States and Canada and its association with Ailanthus altissima (Mill.) (Simaroubaceae) is an interesting subject to be investigated. This plant is an ornamental introduced from Asia and now considered one of the most serious weeds in the United States. It was first planted near the University of Pennsylvania, Philadelphia, in 1784 (W. Thomas, pers. comm.) and from there it spread over the entire country. Once it reached southern Texas, where presumably aurea was already present, the moth started to move north. By 1856 it had reached Georgia, as indicated by the material described by Fitch (1856: 486). Riley (1869: 151) found it common in Missouri, feeding on ailanthus. These records indicate that this showy and common moth was absent in the region before the introduction of ailanthus, and the approximately 70-year gap between the introduction of the host, to the first record of the moth by Fitch, is the time it took the plant to move south and the moth to move north.

Apart from the hosp-plant records mentioned above, the larvae have been reared on the following Simaroubaceae: Castela peninsularis, C. polyandra and C. emory in the United States (Powell et al. 1973: 177), Simarouba amara in Costa Rica (Janzen, pers. com.) and S. glauca in México (by the present author).

\section{Atteva floridana (Neumoegen) sp. rev.} (Fig. 6)

Oeta compta var. floridana Neumoegen, 1891: 123. Lectotype + , USA: Florida, Upper Indian River (USNM), here designated [examined].

This species has been wrongly synonymized under $A$. gemmata (Holland 1903: 424, pl. 48, fig. 37; Dyar 1903: 490), then recognized as a valid species (Walsingham (1914: 328; Kimball 1965: 291), and finally synonymized under punctella [=pustulella] (Heppner \& Duckworth 1983: 26; Heppner 1984: 56). It is restricted to southern Florida, including the Keys, (except for one + from Mississippi, St. Louis Bay, Hancock Co., in USNM). It might be an extreme form of aurea, showing marks much reduced, with predominance of orange, as also illustrated in Holland (1903: pl. 48, fig. 37 [as gemmata], and by Covell (1984: 431, pl. 62, fig. 5) [as punctella]. The genitalia are almost identical to those of aurea and pustulella. However, despite aurea, widespread along Eastern North America, and ranges side by side with floridana in Southern Florida, no intermediate forms between the two have been found. Dyar (1897: 48), who studied the early stages, also stated that the larvae of floridana, found feeding on Simarouba glauca, are distinct from those of aurea. For these reasons both forms are retained as distinct, waiting for more detailed studies of their biology. In case it is proved that it is a good species, it might be considered as endangered. O. floridana was described from an unspecified number of specimens. Only the female mentioned above was traced in the USNM.

\section{Atteva gemmata (Grote) sp. rev.}

(Fig. 7)

Oeta gemmata Grote, 1873: 93. Holotype [?], CUBA. [No further data] (Poey) (ANS) [not traced].

Oeta fastuosa Zeller, 1877. Holotype 우, CUBA. [No further data] (MNHU) [colour image examined]. Synonymized by Walsingham, (1914: 328).

This species, endemic to Cuba, is very similar to the next species (rawlinsi) from Hispaniola but half its size. In gemmata the dots are reduced in number and connected to each other forming small, vertical, white lines.

Both available names have been wrongly synonymized under punctella $[=$ pustulella] (Walsingham 1897: 112) and reinstated as a valid species (Meyrick 1914: 21; Walsingham 1914: 328). However, it seems that both works were overlooked by Heppner \& Duckworth (1983: 26) and by Heppner (1984: 56) who continued to follow Walsingham's (1897) synonymy.

\section{Atteva rawlinsi sp. n.}

(Fig. 8)

This species, endemic to the Dominican Republic, is similar to the former, but is considerably larger, with the blackish areas occupied by numerous small, white dots, not forming vertical lines. Male genitalia are almost identical to those of the former, but with vesica devoid of cornuti in gemmata, whereas in rawlinsi the vesica is armed with multiple long, thin, loose cornuti, the longest ones almost half the size of aedeagus.

Etymology: Named in honour of John E. Rawlins, CMNH, who collected the series of specimens studied here.

Material studied. Holotype $\sigma^{x}$, DOMINICAN REPUBLIC: Barahona. $9.2 \mathrm{~km}$ NW Paraiso, confluence of Rio Nizao/and Rio Coltico. 1803N, 71-12W, 230 m, 9-10 Aug 1990 (J. Rawlins, S. Thomson/CMNH383,805) (CMNH). Paratypes: DOMINICAN REPUBLIC: $2 \sigma^{x}, 3$ ㅇ, [same data as holotype] (CMNH, VOB); $23 \sigma^{x}, 19$ ㅇ, Azua, east side of crest, Sierra Martin Garcia, 7 km WNW Barrero, 18-21N, 70-58W, 860 m, 25-26 July 1992 (C. Young, R. Davidson, S. Thompson, J. Rawlins), cloud forest adjacent to disturbed forest (CMNH); $1 \sigma^{x}$, Dajabon, 9 km S Loma de Cabrera, 19-21N, 71-37W, 620 m, 12 July 1992 (J. Rawlins, S. Thompson, C. Young, R. Davidson), disturbed pastures in mesic woodland $(\mathrm{CMNH}) ; 1$, Elias Pina, north slope Sierra de Neiba, $2 \mathrm{~km}$ SW Canada, $7 \mathrm{~km}$ WSW Hondo Valle, 18-42N, 71-45W, $980 \mathrm{~m}$, 29 August 1995 (J. Rawlins, G. Onore, R. Davidson), eroded fields on hillside $(\mathrm{CMNH}) ; 2$ ㅇ, Elias Pina, Sierra de Neiba, $9.2 \mathrm{~km}$ WSW Hondo Valle, 18-41-37N, 71-46-59W, 1874 m, 25 June 2003 (.J. Rawlins, C. Young, R. Davidson, C. Nunez, P. Acevedo, R. de la Cruz), wet mountain forest, pine (CMNH); $4 \sigma^{x}, 3$ \% Independencia, $4 \mathrm{~km} \mathrm{~S}$ Los Pinos, Loma de Vientos, 18-35N, 71-46W, 455 m, 23 July 1992 (R. Davidson, J. Rawlins, S. Thompson, C. Young),semiarid deciduous forest with pastures (CMNH, VOB); $80^{\pi}, 8$ 9 , La Vega, $15 \mathrm{~km} \mathrm{~N}$ Jarabacoa, 21 July 1987 (J. Rawlins, R. Davidson)(CMNH, VOB); $2 \sigma^{x}, 1$ 오, La Vega, Bayacanes, 120 m, 24 July 1987 (J. Rawlins, R. Davidson)(CMNH); 1 
$0^{\pi}$, Monsenor Nouel, $1 \mathrm{~km}$ E Paso Alto de Casabito, $7 \mathrm{~km}$ NW La Ceiba, 19-02N, 70-29W, 1130 m, 28 July 1992 (JR. Davidson, J. Rawlins, S. Thompson, C. Young), cloud forest (CMNH); 1 ㅇ, Pedernales, $26 \mathrm{~km}$ N Cabo Rojo, 18-06N, 71-38W, 730 m, 20 July 1990 (C.W. Young, J.E. Rawlins, S. Thompson)(CMNH); 2 \%, Pedernales, $26 \mathrm{~km}$ N Cabo Rojo, 18-06N, 71-38W, 730 m, 13 July 1990 (J. Rawlins, C. Young, S. Thompson)(CMNH); $1 \sigma^{*}, 1$ 옹, Pedernales, $26 \mathrm{~km} \mathrm{~N}$ Cabo Rojo, 760 m, 17 July 1987 (J. Rawlins, R. Davidson)(CMNH); 5 o 4 우, Pedernales, $30 \mathrm{~km}$ N Cabo Rojo, 18-07N, 71-39W, 1070 m, 23-24 July 1990 (C.W. Young, J.E. Rawlins, S. Thompson)(CMNH); $2 \sigma^{*}, 1$ ㅇ, Pedernales, 30 km N Cabo Rojo, 18-07N, 71-39W, 1070 m, 27 September 1991(R. Davidson, J. Rawlins, S. Thompson, C. Young), reservoir, pine woods $(\mathrm{CMNH}) ; 1 \sigma^{x}$, Pedernales, $9.5 \mathrm{~km}$ N. Cabo Rojo, 18-02N, 71-39W, 35 m, 19 July 1990 (J. Rawlins, C.W. Young, S.A. Thompson)(CMNH); 2 $\sigma^{x}, 1$ ㅇ, Samana, Samana Peninsula, $8 \mathrm{~km} \mathrm{~S}$ Las Galeras, Punta Balandra, 19-11N, 69-14W, 35 m, 10 October 1991 (C. Young, S. Thompson, R. Davidson, J. Rawlins), semiarid scrub-forest on limestone bluffs $(\mathrm{CMNH}) ; 1 \sigma^{x}$, Santiago, $1 \mathrm{~km}$ NE San Jose de Las Matas, 19-21N, 7056W, 540 m, 11 July 1992 (J. Rawlins, S. Thompson, C. Young, R. Davidson), disturbed woodland (CMNH).

\section{Atteva siderea (Walsingham)}

(Fig. 9)

Oeta siderea Walsingham, 1892: 533. Holotype 우 DOMINICAN REPUBLIC ["San Domingo"]. No further data (BMNH) [colour image examined].

This species is similar to gemmata, but smaller. It is easily distinguished by the white head and by the pair of white dots on each tergum. Known only from the Dominican Republic and from two specimens labeled only as "Jamaica" in CMNH.

Material studied. DOMINICAN REPUBLIC: $2 \sigma^{\pi}$, Barahona, $6 \mathrm{~km}$ NW Paraiso, Rio Nizao, 18-02N, 71-12W, 170 m, 25-26 July 1990 (C. Young, J. Rawlins, S.A. Thompson)(CMNH); $\sigma^{x}$, Dajabon, Rio Massacre, 40 m, Balneario Don Miguel, 7 km SW Dajabon, 26.v.1973 (D. \& M. Davis) (USNM); $\sigma^{\pi}$, + , Dajabon, $13 \mathrm{~km} \mathrm{~S}$ Loma de Cabrera, ca. $400 \mathrm{~m}$, 20-22.v.1973 (D. \& M. Davis) (USNM); $2 \sigma^{*}$, Duarte, Reserva Loma Quita Espuela, El Cadillar, $6.7 \mathrm{~km}$ NE San Francisco de Macoris, 1920-12N, 70-08-59W, 280 m, 5 April 2004 (R. Davidson, J. Rawlins, C. Young), weedy regrowth with coffee, cacao, UV light (CMNH); $1 \sigma^{x}, \mathrm{La}$ Vega, $15 \mathrm{~km}$ N Jarabacoa, $240 \mathrm{~m}$, 21 July 1987 (J. Rawlins, R. Davidson)(CMNH); $1 \sigma^{x}, 1$ female, Monte Cristi, $5 \mathrm{~km} \mathrm{NNE} \mathrm{Botoncillo,}$ 19-46N, 71-24W, 50 m, 290-30 November 1992 (R. Davidson, M. Klingler, S. Thompson, J. Rawlins), arid thornscrub (CMNH). JAMAICA: $2 \sigma^{x}$, [civil subdivision and precise locality unknown], Exchange A.N.S.P., CM Acc. 20359 (CMNH).

\section{Atteva sidereoides sp. $\mathbf{n}$.}

(Fig. 12)

Similar to siderea but with orange and white marks much reduced; easily distinguished from the former by the white thorax and by lacking both the distal orange band parallel to termen and the white dots on terga. Male genitalia almost identical to those of the former, except for the saccus, thickened in the middle, whereas thin, gradually tapering towards the tip in siderea.

Etymology: Named in reference to its similarity to $A$. siderea.

Material studied. Holotype $\sigma^{x}$, JAMAICA: St. Ann, near Runaway Bay Cave, 50 ft, 1-2.v. 1973 (D. \& M. Davis) (USNM).

\section{Atteva fulviguttata (Zeller)}

(Fig. 11)

Oeta fulviguttata Zeller, 1873: 231. Holotype + , [ANTILLES] ['Australia?'] (MNHU) [colour image examined].

Syblis glaucopidella Guenée, 1879: 289. Lectotype $\sigma^{x}$, JAMAICA.

[No further data]. (BMNH), here designated [colour image examined]. Synonymized by Walsingham (1892: 17).

Oeta fulviguttella Walsingham, 1892: 17. Misspelling.

This species resembles gemmata and intermedia; differing from both by lacking the white dots on forewings and terga. 'Australia?', as mentioned in the original description is a mislabelling as the species is known only from Jamaica and Hispaniola. P. glaucopidella was described from an unspecified number of specimens. According to K. Sattler (pers. comm.), there are two males syntypes in $\mathrm{BMNH}$ collections. One of them bears the original Guenée label and is here selected as lectotype, the other will be labelled as paralectotype.

Material studied. DOMINICAN REPUBLIC: $1 \sigma^{\star}, 2$ 우, Hato Mayor, Parque Los Haitises, $3 \mathrm{~km}$ W Cueva de Arena, 19-04N, 69-29W, $20 \mathrm{~m}$, 7-9 July 1992 (R. Davidson, J. Rawlins, S. Thompson, C. Young), mesic lowland forest $(\mathrm{CMNH})$.

\section{Atteva intermedia sp. n.}

(Fig. 10)

Intermediate between fulviguttata and gemmata, differing from the former by the presence of white dots on forewings and thorax and from the latter by the reduced number of these dots. Male genitalia almost identical to those of pustulella and aurea, except for the vesica, armed with a single, thin, short cornutus, whereas armed with a few [3-4], thin, long cornuti in the other two.

Etymology: Named in reference to its pattern, intermediate between A. fulviguttata and A. gemmata.

Material studied. Holotype $\sigma^{\star}$, ANTIGUA: Coolidge Airport, xi.1967 (N.L.H.Krauss) (USNM). Paratypes: $7 \sigma^{x} \sigma^{x}, 1 \stackrel{\circ}{\circ}$, same locality and data as holotype (USNM).

\section{Atteva flavivitta (Walker)} (Fig. 15)

Carthara flavivitta Walker, 1866: 1872. Holotype 우, [COLOMBIA]: Santa Marta (BMNH) [colour image examined].

The blackish forewings with the long, slender yellowish central band make this species readily distinguished from all others in the New World. Known only from the type locality and from $1 \sigma^{x}$ (illustrated), and 2 우 in the USNM, collected in the Island of Margarita, Venezuela, by J. F. G. Clarke.

\section{Atteva hysginiella (Wallengren)} (Fig. 13)

Amblothridia hysginiella Wallengren, 1861: 386. Holotype 우, PANAMA. No further data (NHRS) [not examined]. 

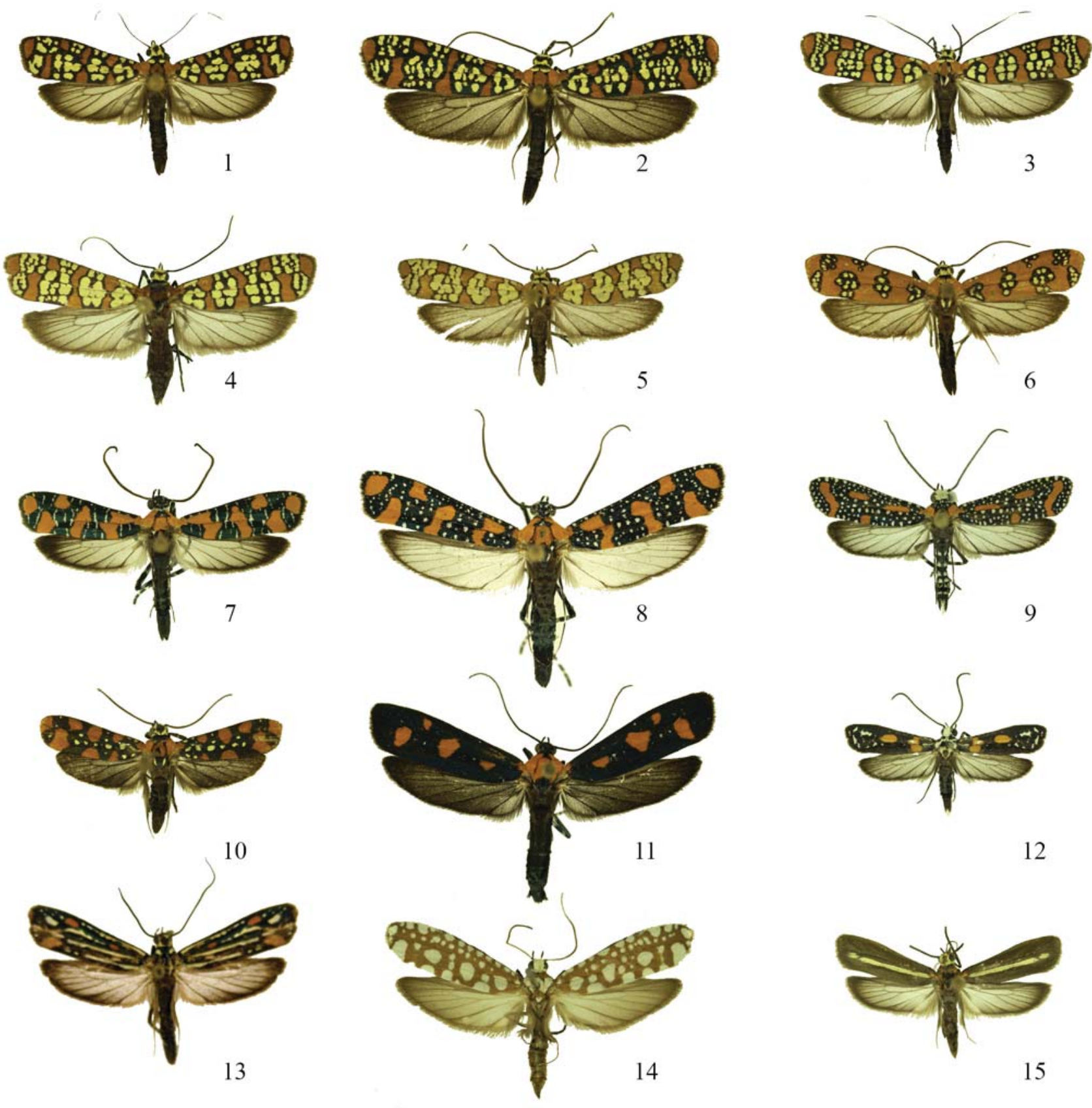

13

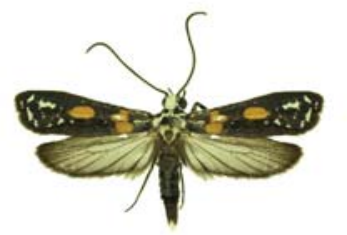

12
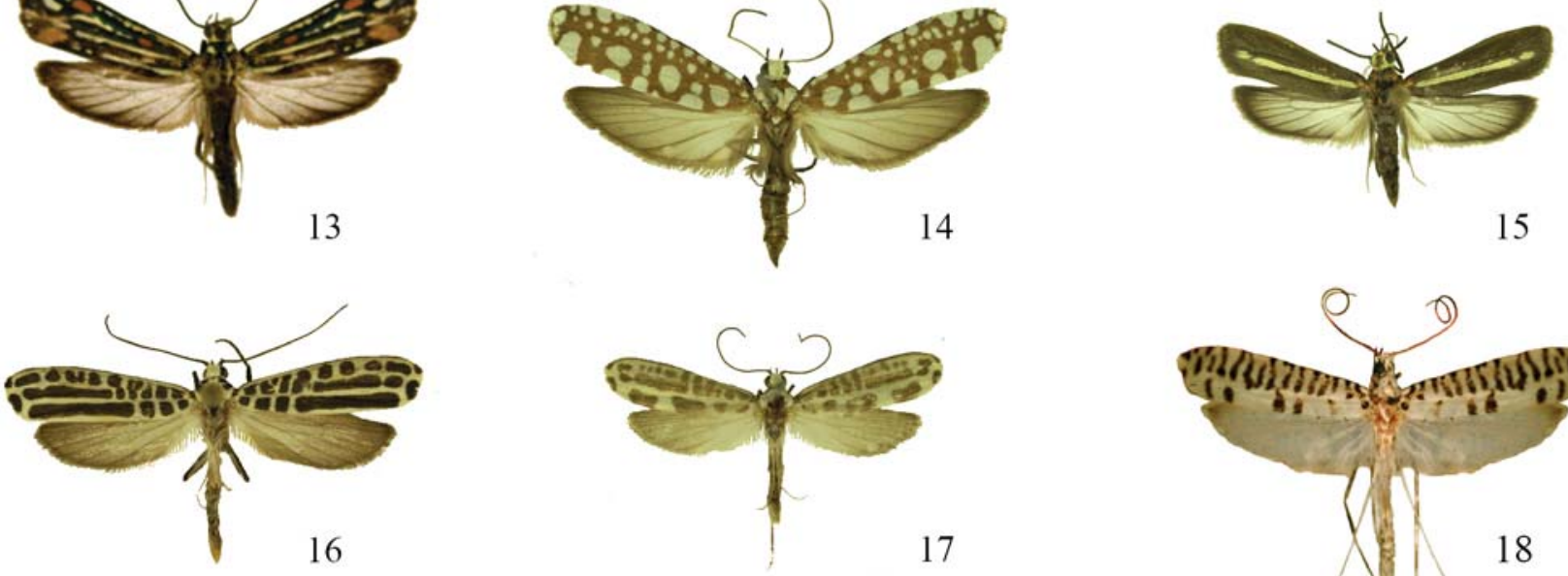

15

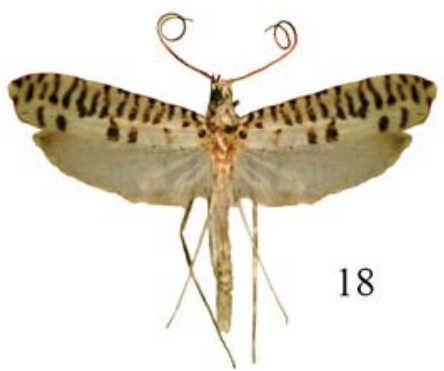

Figs. 1-18. Atteva spp.: 1, A. pustulella (Brazil: BA); 2, A. aurea (f. microsticta) (México: Pue); 3, A. aurea (typical f.) (USA: Md); 4, A. aurea (f. exquisita) (México: Tam); 5, A. aurea (f. edithella) (México: NL); 6, A. floridana (USA: Fl); 7, A. gemmata (Cuba); 8, A. rawlinsi (Dominican Republic; paratype); 9, A. siderea (Dominican Republic); 10, A. intermedia (Antigua, holotype); 11, A. fulviguttata (Dominican Republic); 12, A. sidereoides (Jamaica, holotype); 13, A. hysginiella (Galápagos Ids.); 14, A. cosmogona (Brazil: DF); 15, A. flavivitta (Venezuela); 16, A. zebra (Costa Rica); 17, A. zebrina (Brazil: ES); 18, A. numeratrix (Brazil: PA, holotype). 
Cydosia sylpharis Butler, 1877: [87]. Holotype 올 ECUADOR: Galapagos, Albemarle Id. (BMNH) [not examined]. Synonymized by Meyrick, (1914: 21).

Atteva monerythra Meyrick, 1926: 278. Holotype 우 ECUADOR: Galapagos Id., 31.vii.1924 (C. L. Collenette) (BMNH) [not examined]. Synonymized by Landry \& Landry, (1998: 33).

The three long, slender yellowish lines on a black background, along forewings readily distinguish this species from all others in the genus. Restricted to the Galapagos Id. and by seven specimens in CMNH from Colorado Id., Panama. Rawlins in litt. states that "The seven specimens in $\mathrm{CMNH}$ from Barro Colorado are part of Carnegie Museum Accession Number 12,283, consisting of many insect specimens collected by field ornithologist A. Twomey from several localities including Barro Colorado Island. Specimens from this accession were labelled in error as being from Barro Colorado Island, but include material from localities in Peru, Chile, Galapagos Island, Cocos Island, and Panama. Twomey's notes \#209-240 are for specimens dated April 6, 1939 from Seymour Island, Galapagos, and corresponding specimens of hysginiella are numbered in pencil as $226,228,234,235,236$, 237, and 239. There is no doubt that the Barro Colorado labels are erroneous and I will affix labels asserting their correct origin." Landry \& Landry (1998: 33-39) give a detailed description of adults, immatures and life-history.

\section{Atteva cosmogona Meyrick} (Fig. 14)

Atteva cosmogona Meyrick, 1931: 87. Holotype + , BRAZIL: 'N. Freiburg' [RJ, Nova Friburgo, 1100 m], ex Lederer col., 1870 (NM) [examined].

The coppery-purple forewings, bearing several large round white dots easily distinguish this species from the others. The larvae were found by the author feeding gregariously on the leaves of Simarouba amara (Simaroubaceae) in Planaltina, DF, Brazil. It is apparently an upland species, found to the Atlantic Forest of Brazil, as indicated by specimens collected previously and by the series in the author's collection: MG, Caraça, 1,300 m; Nova Lima, 850 m; RJ, BA, Camacan, Serra Bonita Reserve, $800 \mathrm{~m}$. Also two females from SC, [Seara], Nova Teutonia (Plaumann), in the USNM.

\section{Atteva numeratrix Meyrick}

(Fig. 18)

Atteva numeratrix Meyrick, 1930: 262. Holotype ơ, BRAZIL: PA, [Santarém] Taperinha, 21-30.vi.1927 (Zerny) (NM) [examined].

This is a whitish species, presumably related to zebra, with forewings covered by numerous thin, transverse, copperypurple lines on costal half and a few elongate dots along dorsum. Only the type specimen is known.

\section{Atteva zebra Duckworth}

(Fig. 16)

Atteva zebra Duckworth, 1967: 71. PANAMA: Canal Zone, Barro
Colorado Id., 1-9.v.[19]64 (W. D. \& S. S. Duckworth) (USNM) [examined].

The 'zebra' pattern makes this species readily distinct from any other in the genus. Known only from Costa Rica and Panama.

The $3^{\text {rd }}$. tergite of male of this and the related species (numeratrix, zebra and zebrina) is folded, forming a groove that accommodates the hind tibial hair pencil. The hind tibiae are bent inwards, joining together above the groove, to facilitate the attachment of the hair pencil inside it. This groove is presumably a pheromone gland whose release of scent is enhanced by the hair pencil. If proven to be true, this gland system refers to "Type 5" of Scoble (1995: 163). Duckworth (1967: 72) referred to this gland as "a pair of hair pencils enclosed in a pocket on the third abdominal tergite of male". This mistake is easily explained as when the abdomen is removed for dissection, the hair pencils detach from the tibiae and are retained inside the groove.

\section{Atteva zebrina sp. n.}

(Fig. 17)

Very similar to the former, but much smaller and paler, with reduced marks on the forewings. Male genitalia with valvae shorter and gnathos with lateral margins parallel, not constricted basally as in zebra.

Etymology: Named in reference to its similarity to A. zebra.

Material studied. Holotype $\sigma^{\pi}$, BRAZIL: ES, Linhares, 40m, 1618.ix.1991 (Becker, no. 80824). Paratypes: $1 \sigma^{\pi}$, same data as holotype 1 우, BA, Camacan, 400-700m, 21-30.ix.1991 (Becker, no. 84337) (VOB).

Acknowledgements. This article could not have been written without the collaboration from the following colleagues who did their best to provide free access to the collections under their care, supplied specimens, colour images of several type-specimens, copies of old literature not available to the author, and much other valuable information as stated in the text: D. R. Davis, P. Gentili, S. Miller (USNM), D. Janzen (University of Pennsylvannia, Philadelphia), J.-F Landry (Central Experimental Farm, Ottawa, Canada), J. E. Rawlins $(\mathrm{CMNH}), \mathrm{K}$. Sattler $(\mathrm{BMNH})$ and W. Thomas (New York Botanical Garden). Anthony Raw (Universidade Estadual de Santa Cruz, Ilhéus, Bahia), revised the text, and I. Willems (Porto Seguro, Bahia), prepared the colour plate.

\section{REFERENCES}

Berg, C. 1880. Observaciones sobre la família Hyponomeutidae (continuación). Anales de la Sociedad Científica Argentina 10: $99-109$.

Biezanko, C. M. 1961. Olethreutidae, Tortricidae, Phaloniidae, Aegeriidae, Glyphipterygidae, Yponomeutidae, Gelechiidae, Oecophoridae, Xylorictidae, Lithocolletidae, Cecidoseidae, Ridiaschinidae, Acrolophidae, Tineidae and Psychidae da Zona Sueste do Rio Grande do Sul. Arquivos de entomologia, Pelotas, 13: $1-16$.

Biezanko, C. M.; A. Ruffinelli \& C. S. Carbonell. 1957. Lepidoptera del Uruguay. Revista de la Facultad de Agronomía, Montevideo, 46: $1-152$. 
Busck, A. 1908. Descriptions of North American Tineina. Proceedings of the Entomological Society of Washington 9: 85-95.

Busck, A. 1912. New Microlepidoptera from Mexico. Proceedings of the Entomological Society of Washington 14: 83-87.

Butler, A. G. 1877. On the Lepidoptera, Orthoptera, and Hemiptera collected during the visit of H. M. S. 'Peterel' to the Galapagos Islands. Proceedings of the Zoological Society of London 1877: $86-91$.

Clemens, B. 1861. Contributions to American Lepidopterology. 7. Proceedings of the Academy of Natural Sciences, Philadelphia, 1860: 522-547.

Covell, C. V. 1984. A field guide to the moths of Eastern North America. Boston, Houghton Mifflin. 496 p.

Dugdale, J.; N. P. Kristensen; G. S. Robinson \& M. J. Scoble. 1999. The Yponomeutoidea, p. 119-130. In: N. P. Kristensen (ed.). Handbook of Zoology. Lepidoptera, moths and butterflies. V. 1. Berlin, Walter de Gruyter. $491 \mathrm{p}$.

Duckworth, W. D. 1967. A new species of Atteva from Central America. Proceedings of the Entomological Society of Washington 69: $69-72$.

Dyar, H. G. 1897. Oeta floridana Neumoegen. Journal of the New York Entomological Society 5: 48.

Dyar, H. G. 1903. A list of the North American Lepidoptera. Bulletin United States National Museum 52: 1-723.

Fabricius, J. C. 1787. Mantissa insectorum. Copenhagen, Proft. 382 p.

Fabricius, J. C. 1794. Entomologia Systematica. Part 2. Copenhagem, Proft. 349 p.

Fabricius, J. C. 1798. Suplementum entomologiae sistematicae. Copenhagen, Proft \& Storch. 572 p.

Fitch, A. 1856. Third report on the noxious and other insects of the State of New York. Transactions of the New York State Agricultural Society 16: 315-490.

Fletcher, T. B. 1929. A list of generic names used for Microlepidoptera. Memoirs of the Department of Agriculture of India (Ent.) 11: $1-244$

Grote, A. R. 1865. Notes on the Bombycidae of Cuba. Proceedings of the Entomological Society of Philadelphia 5: 227-255.

Grote, A. R. 1873. Contribution to a knowledge of North American moths. Bulletin of the Buffalo Society of Natural History 1: 73-94.

Guenée, A. 1879. Études sur les Yponomeutides. Annales de la Société Entomologique de France 48: 281-290.

Hayward, K. J. 1969. Datos para el estudio de la ontogenia de lepidopteros argentinos. Fundación Miguel Lillo, Miscelánea 31: $1-142$

Heppner, J. B. 1984. Yponomeutidae, p. 55-56. In: J. B. Heppner (ed.). Atlas of Neotropical Lepidoptera. Checklist, Part I. The Hague, W. Junk xxvii $+112 \mathrm{p}$.

Heppner, J. B. \& W. D. Duckworth. 1983. Yponomeutidae, p. 26-27. In: R. W. Hodges, T. Dominick, D. R. Davis, D. C. Ferguson, J. G. Franclemont, E. G. Munroe and J. A. Powell (eds.). Check list of the Lepidoptera of America North of México. London, Classey. $284 \mathrm{p}$.

Holland, W. J. 1903. The moths book. Doubleday, Page \& Co. 479 p., $48 \mathrm{pls}$.

Hübner, J. 1816-[1826]. Verzeichniss bekannter Schmettlinge [sic]. Augsburg. 431+72 p.

Kimball, C. P. 1965. Lepidoptera of Florida. Florida Department of Agriculture, Gainesville. 363 p.

Landry, B. \& J. F. Landry. 1998. Yponomeutidae of the Galapagos Islands, with the description of a new species of Prays (Lepidoptera:
Yponomeutoidea). Tropical Lepidoptera 9: 31-40.

Meyrick, E. 1914. Hyponomeutidae, Plutellidae, Amphitheridae. Lepidopterorum catalogus 19: 1-20.

Meyrick, E. 1926. On the Microlepidoptera from the Galapagos Islands and Rapa. Transactions of the Entomological Society of London 74: 269-278.

Meyrick, E. 1930. Ergebnisse einer zoologischen Sammelreise nach Brasilien, insbesondere in das Amazonasgebiet, ausgeführt von Dr. H. Zerny. V Teil. Micro-Lepidoptera. Annalen des Naturhistorischen Museums in Wien 44: 223-268.

Meyrick, E. 1931. Hyponomeutidae. Exotic Microlepidoptera 4: $87-91$.

Moore, F. 1867. On the lepidopterous insects of Bengal. Proceedings of the Zoological Society of London 1867: 612-686.

Neumoegen, B. 1891. New Rhopalocera and Heterocera. Canadian entomologist 23: $122-126$.

Powell, J. A.; J. A. Comstock \& C. F. Harbison. 1973. Biology, geographical distribution, and status of Atteva exquisita (Lepidoptera: Yponomeutidae). Transactions of the San Diego Society of Natural History 17: 175-186.

Riley, C. V. 1869. First report on the noxious, beneficial, and other insects of the State of Missouri. Jefferson City, Missouri State Board of Agriculture. $181 \mathrm{p}$.

Ruffinelli, A. 1967. Insectos y otros invertebrados de interés forestal. Silvicultura, Maldonado, 25: 3-79.

Scoble, M. J. 1995. The Lepidoptera. Form, function and diversity. Oxford, Oxford University. 404 p.

Sefer, E. 1963 [1961]. Alguns dados sobre pragas do marupá. Boletim técnico do Instituto Agronômico do Norte, Pará, 43: 9-12.

Stoll, C. 1781. [Lepidoptera], p. 91-164. In: P. Cramer. De Uitlandsche Kapellen III. Amsterdam, Baalde. 252 p.

Stretch, R. H. 1872-1873. Illustrations of the Zygaenidae and Bombycidae of North America. San Francisco, Author. 242 p.

Swederus, N. S. 1787. Fortfattning af beskrifiningen pa 50 nya species af insekter. Kungliga svenska Vetenskapsakademiens Handlingar 8: 272-290.

Walker, F. 1854. List of specimens of lepidopterous insects in the collection of the British Museum 2: 279-581.

Walker, F. 1863. List of specimens of lepidopterous insects in the collection of the British Museum 28: 287-561.

Walker, F. 1865. List of specimens of lepidopterous insects in the collection of the British Museum 33: 707-1120.

Walker, F. 1866. List of specimens of lepidopterous insects in the collection of the British Museum 35: 1535-2040.

Wallengren, H. D. J. 1861. Lepidoptera, p. 351-390. In: Kongliga Svenska Fregatten Eugenies Resa. Zoologia IV. Stockholm.

Walsingham, Lord [T. de Gray]. 1892. On the micro-lepidoptera of the West Indies. Proceedings of the Zoological Society of London 1891: 492-548.

Walsingham, Lord [T. de Gray]. 1897. Revision of the West-Indian Micro-Lepidoptera, with descriptions of new species. Proceedings of the Zoological Society of London 1897: 54-183.

Walsingham, Lord [T. de Gray]. 1909-1915. Tineina, Pterophorina, Orneodina, Pyralidina and Hepialina (part). In: F. D. Godman \& O. Salvin (eds.). Biologia centrali-americana. Insecta. Lepidoptera-Heterocera. Vol. IV. p. 1-482.

Zeller, P. C. 1873. Beiträge zur Kenntniss nordamerikanischen Nachtfalter, besonders der Microlepidopteren. Verhandlungen der Kaiserlich-Königlichen zoologisch-botanischen Gesellschaft in Wien 23: 201-334.

Zeller, P. C. 1877. Exotische Microlepidoptera. Horae Societatis Entomologicae Rossicae 13: 3-493. 